\title{
S-10-3 Carotenoids in Cancer Chemoprevention and Therapeutic Interventions
}

\author{
L.SANTAMARIA, and A.BiAnCHI-SANTAMARIA *
}

"Camillo Golgi" Institute of General Pathology - Tumor Center ${ }^{\S}$; *Institute of Pharmacology II University of Pavia - 27100 - Pavia - Italy

\section{EXPERIMENTAL CANCER CHEMOPREVENTION BY SUPPLEMENTAL CAROTENOIDS}

In 1973, experimental trials suggested that a diet rich in red carrots delayed the appearance of tumors induced by dymethyl-benzo-(a)-anthracene in mice (1). In 1977 it was reported that an intraperitoneal injection of beta-carotene delayed skin tumor induction in hairless mice exposed to UV-B (290-320 nm) irradiation (2). Subsequently, in 1980, an experimental trial demonstrated that beta-carotene $(\mathrm{BC})$ or canthaxanthin $(\mathrm{CX})$, two carotenoids with and without pro-vitamin A activity respectively, when supplemented at high dosage by diet to albino mice, prevent up to about $60 \%$ skin cancer induced by benzo(a)pyrene (BP) (3). In this experiment, care was taken to start carotenoid supplementation one month before carcinogenic induction and to continue this supplementation to the diet throughout the entire experiment. Groups of animals were irradiated for two hours with long UV light $(300-400 \mathrm{~nm})$ flux $=5.89 \times 10^{3} \mathrm{erg} \mathrm{cm}^{-2} \mathrm{sec}^{-1}$ twice a week half an hour after BP skin painting, to produce the marked photocarcinogenic enhancement (PCE) as reported in the 1960s (4), apparently through a photodynamic process involving oxygen radical species. Analysis of these results demonstrated that both carotenoids completely controlled PCE (5). This effect was independent of provitamin A activity, whereas it was highly dependent on the antioxidant property of CARs. Significantly, the low rate of skin cancer induced by long term exposure to UV light $(300-400 \mathrm{~nm})$ alone was thoroughly controlled by carotenoid supplementation. Furthermore, the skin cancer inhibition by BC and CX was also observed in animals kept in the dark, apparently through the scavenging and/or quenching of oxyradicals and/or $1 \mathrm{O}_{2}$ endogenously produced through BP metabolization to its diol-epoxy derivatives.

On the whole, these results can be taken as the first clearcut experimental evidence that dietary carotenoid supplementation can control the oxygen radical pathology involved in skin cancer inductions by an indirect carcinogen, thus preventing tumor onset, likely at the initiation stage. In the same year (1980), Mathews-Roth also reported the first of her experiments demonstrating that dietary CARs ( $\mathrm{BC}$ or $\mathrm{CX}$ ) can act as antioxidants protecting against skin tumors induced in mice either with UVB light, DMBA \pm croton oil or with DMBA \pm UVB light (6).

In 1981 and 1982, Seifter et al. proved that BC is active against transplanted tumors, by preventive and therapeutic mechanisms, interpreting the effects as due to vitamin A production and immunostimulation $(7,8)$.

In 1984 and 1985, the same methodology used in the above experiment with BP was adapted to try to prevent indirect breast photocarcinogenesis induced in albino Swiss mice, strain 955, by 8-methoxypsoralen (8-MOP) topical application plus long UV light (P-UVA) (9). Later, the same method was applied to try to prevent direct gastric carcinogenicity induced by $\mathrm{N}$-methyl- $\mathrm{N}$ -

$\S$ "Convenzionato" with the Unità Socio-Sanitaria Locale (USSL 77), Pavia 
nitro-N-nitrosoguanidine (MNNG) in rats. In these two experiments prevention was further confirmed at $60-70 \%$, proving that it is active even against direct carcinogenesis (10). These two types of prevention probably occurred at the promotion and progression stages, respectively. All these results prompted investigations by others on different carcinogenic models, as reported in Table I. In this Table attention should be paid to the presumed mechanisms of action, that were based on the principal activities of CARs, namely, antioxidation and retinoid potential

TABLE I. BASIC REFERENCES OF CAROTENOID EFFECTS ON EXPERIMENTAL INDIRECT AND DIRECT CARCINOGENESES AND TUMOR TRANSPLANTATION

\begin{tabular}{|c|c|c|c|c|c|}
\hline YEAR & AUTHOR & $\begin{array}{l}\text { CAROTENOIDS AND } \\
\text { ADMINISTRATION ROUTE }\end{array}$ & CARCINOGENIC MODEL & EFFECT & $\begin{array}{l}\text { ASSUMED } \\
\text { MECHANISM }\end{array}$ \\
\hline 1973 & $\begin{array}{c}\text { DOROGOKUPLA A.G. } \\
\text { ET AL. (1) }\end{array}$ & $\begin{array}{l}\text { RED CARROTS } \\
\text { IN DIET }\end{array}$ & $\begin{array}{l}\text { SKIN CANCER BY DMA } \\
\text { IN MICE AND RATS } \\
\text { (indirect) }\end{array}$ & $\begin{array}{l}\text { PROTECTION } \\
\text { DELAY }\end{array}$ & VITAMIN A \\
\hline 1977 & EPSTEIN J. (2) & $\begin{array}{l}\text { BC } \\
\text { I.P. }\end{array}$ & $\begin{array}{l}\text { UVB SKIN CANCER IN } \\
\text { HAIRLESS MICE } \\
\text { (indirect) }\end{array}$ & DELAY & UNDETERMINED \\
\hline 1980 & $\begin{array}{c}\text { MATHEWS - ROTH } \\
\text { M.M. (6) }\end{array}$ & $\begin{array}{c}\text { BC } \\
\text { CANTHAXANTHIN P.O. }\end{array}$ & $\begin{array}{l}\text { UV-B SKIN CANCER } \\
\text { SKIN CANCER BY DMBA } \pm \\
\text { CROTON OIL OR } \pm \text { UV-B } \\
\text { IN HAIRLESS MICE (indirect) }\end{array}$ & $\begin{array}{l}\text { DELAY } \\
\text { PREVENTION }\end{array}$ & ANTIOXIDANT \\
\hline 1980 & $\begin{array}{l}\text { SANTAMARIA L. } \\
\text { ET AL. (3) }\end{array}$ & $\begin{array}{c}\mathrm{BC}\left({ }^{*}\right) \\
\mathrm{CX} \\
\text { supplemental P.O. }\end{array}$ & $\begin{array}{l}\text { SKIN CARCINOGENESIS } \\
\text { BY BP } \pm \text { UVA } \\
\text { IN MICE } \\
\text { (indirect) }\end{array}$ & $\begin{array}{l}100 \% \text { PREVENTION } \\
\text { OF PCE } \\
60 \% \text { TOTAL } \\
\text { CARCINOGENESIS }\end{array}$ & $\begin{array}{l}\text { ANTIOXIDANT } \\
\text { ACTING AT THE } \\
\text { INITIATION STAGE }\end{array}$ \\
\hline 1980 & $\begin{array}{l}\text { SANTAMARIA L. } \\
\text { ET AL. (3) }\end{array}$ & idem & $\begin{array}{l}\text { UVA LONG TERM SKIN } \\
\text { PHOTOCARCINOGENESIS } \\
\text { IN MICE } \\
\text { (indirect) }\end{array}$ & $100 \%$ PREVENTION & ANTIOXIDANT \\
\hline 1981 & $\begin{array}{l}\text { SEIFTER R. } \\
\text { ET AL. (7) }\end{array}$ & $\begin{array}{l}\text { BC } \\
\text { P.O. }\end{array}$ & $\begin{array}{l}\text { ADENO-CARCINOMA } \\
\text { C3HBA IN MICE } \\
\text { (transplantation) }\end{array}$ & $\begin{array}{l}\text { DELAYPREVENTION } \\
\text { REGRESSION }\end{array}$ & $\begin{array}{l}\text { VITAMINA+ } \\
\text { IMMUNOSTIMUL. }\end{array}$ \\
\hline 1982 & $\begin{array}{l}\text { SEIFTER R. } \\
\text { ET AL. (8) }\end{array}$ & $\begin{array}{l}\mathrm{BC} \\
\mathrm{P} . \mathrm{O}\end{array}$ & $\begin{array}{l}\text { M-MU SV IN MICE } \\
\text { (transplantation) }\end{array}$ & $\begin{array}{c}\text { DELAY/PREVENTION/ } \\
>\text { REGRESSION }\end{array}$ & $\begin{array}{l}\text { VITAMIN A + } \\
\text { IMMUNOSTIMUL. }\end{array}$ \\
\hline 1984 & $\begin{array}{l}\text { SANTAMARIA L. } \\
\text { ET AL. (9) }\end{array}$ & $\begin{array}{l}\text { BC } \\
C X \\
\text { P.O. }\end{array}$ & $\begin{array}{l}\text { BREAST PHOTO-CARCI- } \\
\text { NOGENESIS BY 8-MOP } \\
\text { (PUVA) IN MICE } \\
\text { (indirect) }\end{array}$ & $60 \%$ PREVENTION & $\begin{array}{c}\text { ANTIOXIDANT } \\
\text { ACTING AT THE } \\
\text { PROMOTION STAGE }\end{array}$ \\
\hline $1984 / 88$ & $\begin{array}{c}\text { ALAM B.S } \\
\text { ET AL. }(11,12,13)\end{array}$ & $\begin{array}{c}\text { BC CX } \\
\text { 13-CIS-RETINOIC ACID } \\
\text { P.O. }\end{array}$ & $\begin{array}{c}\text { SALIVARY GLAND TUMORS } \\
\text { BY DMBA IN RATS } \\
\text { (indirect) }\end{array}$ & $\begin{array}{l}\text { REDUCTION OF INCIDENCE } \\
\text { AND TUMOR WEIGHT }\end{array}$ & $\begin{array}{c}\text { ANTIOXIDANT } \\
\text { NO RETINOL EFFECT }\end{array}$ \\
\hline 1985 & $\begin{array}{l}\text { RAI A.S. AND KATZ } \\
\text { (14) }\end{array}$ & $\begin{array}{l}B C \\
\text { I.P. }\end{array}$ & $\begin{array}{l}\text { CHROMOSOME BREAKS } \\
\text { IN MICE INDUCED BY BP } \\
\text { OR MITOMYCIN C }\end{array}$ & $\begin{array}{c}\text { ANTICLASTOGENIC } \\
\text { ACTION }\end{array}$ & ANTIOXIDANT \\
\hline $1986 / 87$ & $\begin{array}{l}\text { SCHWARTZ, SUDA, } \\
\text { ET AL. }(15,16,17,18)\end{array}$ & $\begin{array}{c}\mathrm{BC}, \mathrm{CX}, \text { ALGAE EXTRACTS } \\
\text { TOPICAL }\end{array}$ & $\begin{array}{l}\text { DMBA INDUCED CHEEK } \\
\text { POUCH SCC IN HAMSTERS } \\
\text { (indirect) }\end{array}$ & $\begin{array}{l}\text { INHIBITION } \\
\text { REGRESSION }\end{array}$ & $\begin{array}{l}\text { ANTIOXIDANT ACTING } \\
\text { AT THE INITIATION AND } \\
\text { PROGRESSION STAGE }\end{array}$ \\
\hline 1987 & $\begin{array}{l}\text { TEMPLE. N.J. } \\
\text { AND BASU T. (19) }\end{array}$ & $\begin{array}{l}\text { BC } \\
\text { P.O. }\end{array}$ & $\begin{array}{c}\text { COLON CANCER BY DMH } \\
\text { IN MICE } \\
\text { (indirect) }\end{array}$ & $\begin{array}{c}50 \% \text { ADENOMA } \\
100 \% \text { ADENOCARCINOMA } \\
\text { PREVENTION }\end{array}$ & $\begin{array}{l}\text { ANTIOXIDANT + } \\
\text { IMMUNOSTIMUL. }\end{array}$ \\
\hline 1991 & $\begin{array}{l}\text { MATHEWS ROTH } \\
\text { M.M. ET AL. (20) }\end{array}$ & $\begin{array}{l}\text { BC, CX } \\
\text { P.O. }\end{array}$ & $\begin{array}{l}\text { URINARY BLADDER CANCER } \\
\text { INDUCED BY OH-BBN IN MICE } \\
\text { (indirect) }\end{array}$ & $\begin{array}{l}50 \% \text { PREVENTION BY BC } \\
\text { NO PREVENTION BY CX }\end{array}$ & RETINOID ACTION \\
\hline
\end{tabular}

(*) All supplementation according to Santamaria et al. started one month before carcinogenic treatments and continued throughout the experiments. 
(production of retinal <-> retinol $\rightarrow>$ retinoic acid from BC). Apparently, these activities were responsible for many combined effects other than anticarcinogenesis, i.e. immunostimulation, antiatherosclerosis, antiaging, antimutagenesis, anticlastogenesis, antiviral effects. BC and CX proved to be antimutagenic on S. typhimurium TA 102 and anti-malignant transformation in cell cultures $(21,22)$. In the case of chemoprevention against urinary bladder, as observed by Mathew-Roth et al. (20), BC was active, whereas CX was not, thus indicating that $\mathrm{BC}$ retinoid potential was responsible for its mechanism of action.

\section{HUMAN INTERVENTION TO PREVENT SECOND PRIMARY NEOPLASMS}

All the above animal experiments are in keeping with the concept of cancer chemoprevention (23) consisting in the reversion of precancerous lesions. Thus, when cancer chemoprevention was applied to human interventions, it was called primary when preventing primary malignancies; it was called secondary in any post radical surgery condition preventing the expression of second primary malignancies in districts where a latent initiation is presumed to persist.

Following this rationale for secondary chemoprevention, a first clinical case report of 15 cases was carried out in the 1980's (24) and updated in 1990 (22), relative to cancers radically excised in compartments including mammary gland, lung, urinary bladder, colon-rectum, head and neck. Here the data demonstrated that in all patients supplementation with $\mathrm{BC}+\mathrm{CX} 40$ $\mathrm{mg}$ /day prevented second primary malignancies well beyond their expected disease free intervals.

\section{SYNERGISTIC THERAPEUTIC ACTIVITY OF BC AND RETINOL IN PREMENSTRUAL MASTALGIA WITH BENIGN BREAST DISEASE}

The potential use of retinoids for chemoprevention of experimental breast carcinomas as reported in a 1980 editorial (25) rekindled an old interest in high dosage vitamin A treatment of benign breast disease (BBD) with premenstrual mastalgia. Nevertheless, the encouraging results obtained in 1984 both with regard to complete or partial responses of BBD and pain reduction were still associated with toxic effects, because of the high vitamin A dosage $(150,000 \mathrm{IU} /$ day for 3 months) required to achieve these clinical results (26). Hence, it was posited in the Pavia Tumor Center that mastalgia might possibly be treated with BC as a vitamin A-precursor and as a per se antioxidant agent devoid of any toxicity. This approach, however, proved to be unsuccessful. But, when BC oral supplementation at low dosage $(20 \mathrm{mg} /$ day $)$ was associated with intermittent retinol (palmitate or acetate ester) administration at very high dosages $(300,000$ I.U./day) for seven days just before the beginning of the menstrual period, the same positive responses as mentioned above were detected soon after the first menstrual cycle in women aged 21-41 (average 35 yrs.). Remarkably, no toxic side effects were detected, even after prolonged treatment (24 months to date) (22) with a clear cut synergism. This treatment had no effect in pre-menopausal non-cyclical mastalgia (women aged 41-50)

To explain the mechanism of action of BC-Vitamin A synergism it is suggested that what is involved is the powerful antioxidant activity of $\mathrm{BC}$ in that this is efficient in cutting down all the oxygen radicals produced by the phlogistic component of the syndrome associated with the greater water solubility of retinol permitting it to cross the oedema barrier faster than $\mathrm{BC}$ and to exert its possible antiprolactin-oestrogen activity. The synergistic effect may also depend on a competition for a receptor due to the same structure in $\mathrm{BC}$ and retinol molecular end points.

\section{ANTICLASTOGENIC ACTION BY CARs IN HUMANS}

In a one year-study, 9 healthy human donors were supplemented with beta-carotene (BC) plus canthaxanthin $(\mathrm{CX})$, to determine the effect of carotenoids on chromosomal damage 
(micronuclei) induced in the donors' lymphocyte cell cultures by exposure to bleomycin (BLM), an antineoplastic drug that has been shown to produce chromosomal aberrations through the production of free radicals. The data showed that the micronuclei induced by BLM in human lymphocyte cell culture was decreased up to $50 \%$ when lymphocytes were from donors supplemented with BC at different doses. Significantly, the above micronuclei induction was inversely correlated with donors' carotenoid blood levels (27).

\section{BC BIOMODULATION OF THE HOST IMMUNE RESPONSE BY INCREASE IN MOUSE LIVER MASTOCYTES}

The mechanism of action of $\mathrm{BC}$ tumor chemoprevention is due to its antioxidant activity and/or to its retinoid potential, as reported above. Moreover, it has been shown that $\mathrm{BC}$ plays a role in tumor inhibition also influencing host immune response, including lymphopoiesis, thymopoiesis, enhancement of skin allograft rejection, and antiviral host reaction. In this connection, attempts have been made to ascertain the immunostimulating effect of $\mathrm{BC}$ in nonneoplastic/non-infected experimental animals and to estabilish whether such an effect can be evaluated in a quantitative manner.

Since an extensive survey on several immunologic parameters revealed an enhancement of defense cells in BC treated animals, a model system was chosen to quantitate this enhancement. The number of mastocytes (cells involved in tumor inhibition and in host defense against tumor) was thus measured in liver imprints from BALB/c mice, stained May Grunwald/Giemsa. This task was carried out using a computerized image analyzer connected to a microscope via a video camera. Data acquired through digitalization of microscope images showed a dramatic increase in the number of mastocytes in liver imprints from $\mathrm{BC}$ treated animals. This increase was quantifiable in a $23: 1 \mathrm{BC}$ treated vs. control increase ratio, thus revealing the important role of mastocytes in modulating host immune response. This may well explain the increase in survival observed in tumour transplanted mice when the animals are BC supplemented (28).

\section{BC SUPPLEMENTATION AS A THERAPEUTIC ADJUVANT IN NON-SURGICALLY TREATABLE LUNG CANCER PATIENTS}

On the basis of the above $\mathrm{BC}$ biomodulation and Seifter's data on $\mathrm{BC}$ immunostimulation and local barrier to malignancy $(7,8)$, four non-surgically treatable lung cancer patients were admitted from July 1989 to July 1990 , to a tentative trial in an effort to increase their expected median survivals by BC supplementation at high dosage $(80 \mathrm{mg} /$ day $)$. The recruited patients had the following characteristics: three of them suffered from squamous cell carcinoma $T_{3} N_{1} M_{x}$ and one from limited type microcytoma; none of them could undergo chemotherapy because of their advanced age and/or concomitant chronic pathologies, nevertheless, they performed well on the Karnowsky Index (K.I.) with a score of 100 or almost; two of them underwent telecobalt therapy. Their expected median survivals ranged from 8 to 12 months. They all complied with the prescription of two gelatin pearls of BC $20 \mathrm{mg}$ each after the two main daily meals. Significantly, the first year follow-up showed a stable disease (SD) for all patients due to a tumor mass stationary status as monitored, in a blind manner, by both chest X-ray and K.I. performance. The $X$ ray showed rounded opacities sharply delimited from the surrounding tissues. In one case, the squamous cancer opacity in stationary status underwent an apparent colliquation in 2 years, step by step. The patient died from "atypical pneumonia" at the lobe with cancer with no diffusion of the latter. The updated (August 1991) overall survivals, including those of the two surviving patients, appeared to be increased from 1.5 to 3 times more than their expected median survivals, with a sustained high K.I. performance over a long period of time. The significance of these data apparently depended on the strict admission criteria adopted including no chemotherapy and 
especially high K.I. performance. The high dosage BC efficacy inducing an increase in overall survivals should in all probability be attributed to both antioxidant and retinoid potential activities of $\mathrm{BC}$, thus displaying immunostimulation, antiproliferation and differentiation effects, thus accounting for the build-up of biological barriers against malignancy (29).

\section{SUMMARY}

Carotenoid (CARs: beta-carotene BC and/or canthaxanthin CX) supplementation have been shown to be chemopreventive in animals, since 1980, against direct or indirect chemical carcinogenesis/photo-carcinogenesis of the skin, breast, stomach, salivary glands, colon-rectum, urinary bladder, and against transplanted tumors. This action could be either independent of or dependent on pro-vitamin $\mathrm{A}$ activity of $\mathrm{BC}$. In vitro, both $\mathrm{BC}$ and $\mathrm{CX}$ proved to be antimutagenic and to have anti-malignant transformation properties in cell cultures. Preliminary interventions in humans with $\mathrm{BC} \pm \mathrm{CX}$ prevented the onset of second primary tumors in lung, colon, urinary bladder, and head and neck. The powerful antioxidant properties of CARs, possibly associated with their retinoid potential, played a role in all the above observations, producing free-radical quenching and immunostimulation.

The current development of the above investigations on CARs in the Pavia University Tumor Center has so far achieved the following data: 1) the anticlastogenic action of CARs in humans was demonstrated by the reduction of the micronuclei induced by bleomycin in cultured lymphocytes from subjects supplemented with CARs; 2) the immunoresponse modulated by BC augmented in mice, thus lengthening survivals after transplantation of ascites tumors along with a dramatic increase in liver mastocytes; 3 ) a synergism between $\mathrm{BC}$ and retinol, previously shown in pre-menstrual mastalgia (with BBD or otherwise), was confirmed as a relevant tool to obtain marked relief and/or complete recovery from breast pain only in cyclical mastalgia with no side effects at all in 20-42 aged women; 4) finally, a tentative trial with $\mathrm{BC} 80 \mathrm{mg} /$ day in nonsurgically treatable human lung cancer cases performing high K.I. on admission, achieved a S.D. status as monitored by X-ray and high K.I. for one year, leading to an increase (1.5 - 3 times more) in overall survival with respect to expected median survival. The latter was consistent with a therapeutic rather than a preventive effect by $\mathrm{BC}$.

\section{ACNOWLEDGEMENTS}

Partially supported by the Ministero della Sanità, Roma, Dir. Gen. Serv. Med. Soc., Div. IV, (Contract N. 500/4/RSC/57.3/T/1879 - 1989). English text revised by Dr. A.P. Baldry, Supply Professor of Medical English, Univ. of Pavia.

KEYWORDS: carotenoids / antioxidants / retinol / anticarcinogenesis / chemoprevention / human interventions / mastalgia.

\section{REFERENCES}

1) Dorogokupla A.C., Troitzkaia, E.G., Adilgereieva, L.K., Postolnikov, S.F., Chekrigina, Z.P. Effect of carotenc on the development of induced tumors. Zdravoor. Kazak. 10, 32-34, 1973.

2) Epstein, J.H. Effects of B-carotene on ultraviolet induced cancer formation in the hairless mouse skin. Photochem. Photobiol., 25, 211-213, 1977.

3) Santamaria, L., Bianchi, A., Arnaboldi, A., and Andreoni, L. Prevention of the benzo(a)pyrene photocarcinogenic effect by beta-carotene and canthaxanthine. Preliminary study. Boll. Chim. Farmaceutico, 119 : $745-748,1980$.

4) Santamaria, L., Giordano, G.G., Alfisi, M., and Cascione, F. Effects of light on 3,4-benzpyrene carcinogenesis. Nature, 210, 824-825, 1966.

5) Santamaria, L., Bianchi, A., Arnaboldi, A., Andreoni, L., and Bermond, P. Dietary carotenoids block photocarcinogenic enhancement by benzo(a)pyrene and inhibit its carcinogenesis in the dark. Experientia, 39 , 
1043-1045., 1983.

6) Mathews-Roth, M.M. Carotenoid pigments as antitumor agents. In Nelson, J.D., and Grassi, C., Eds. Current Chemotherapy and Infection disease. Washington, DC, Am. Soc. Microbiol., pp. 1503-1505, 1980.

7) Seifter, E., Rettura, G. Stratford, F. and Levenson, S.M. CH3BA tumor prevention and treatment with betacarotene. Fed. Proc. 40: 652-656, 1981

8) Seifter, E., Rettura, G., Padawer, J., and Levenson, S.M. Moloney murine sarcoma virus tumors in CBA/J mice: chemopreventive and chemotherapeutic action of supplemental beta-carotene. J.N.C.I., 68 (5), 835-840, 1982.

9) Santamaria, L., Bianchi, A, Andreoni, L., Santagati, G., Arnaboldi, A., and Bermond, P. 8-Methoxypsoralen photocarcinogenesis and its preventiom by dietary carotenoids. Preliminary results. Med. Biol. Environn., 12, 533537, 1984.

10) Santamaria, L., Bianchi, A., Arnaboldi, A., Andreoni, L., Santagati, G., Ravetto, C., Bianchi, L., Pizzala, R., and Bermond, P. Supplemental carotenoids prevent skin cancer by benzo(a)pyrene, breast cancer by PUVA, and gastric cancer by MNNG. Relevance in human chemoprevention. In: Meyskens, F.L., and Prasad, K.N. (Eds.) Vitamins and Cancer-Human Cancer Prevention by Vitamins and Micronutrients", Clifton, NY, The Humana Press, pp. 139-159, 1985.

11) Alam, B.S., Alam, S.Q., Weir, J.C., Jr., and Gibson, W.A. Chemopreventive effects of beta-carotene and 13cis-retinoic acid on salivary gland tumors. Nutr. Cancer, 6, 4-12, 1984.

12) Alam, B.S.,and Alam S.Q. The effect of different levels of dietary beta-carotene on DMBA-induced salivary gland tumors. Nutr. Cancer, 9, 93-101, 1987.

13) Alam, B.S., Alam, S.Q., and Weir, J.C. Jr. Effects of excess vitamin A and canthaxanthin on salivary gland tumors. Nutr. Cancer, 11, 233-241, 1988.

14) Rai, A.S. and Katz, M. Beta-carotene as an inhibitor of benzo(a)pyrene and mitomycin $C$ induced chromosomal breaks in the bone marrow of mice. Can. J. Genet. Cytol., 27, 598-602, 1985.

15) Suda, D., Schwartz, J., and Shklar, G. Inhibition of experimental oral carcinogenesis by topical beta-carotene. Carcinogenesis, 7, 711-715, 1986.

16) Schwartz, J.,Suda, D., and Light, G. Beta carotene is associated with the regression of hamster buccal pouch carcinoma and the induction of tumor necrosis factor in macrophages. Biochem. Biophys. Res. Commun., 136, 1130-1135, 1986.

17) Suda, D., Schwartz, J., and Shklar, G. GGT reduction in beta carotene inhibition of hamster buccal pouch carcinogenesis. Eur. J. Cancer Clin. Oncol., 23, 43-46, 1987.

18) Schwartz, J., and Shklar, G. Regression of experimental hamster cancer by beta-carotene and algae extracts. $J$. Oral. Maxillofac. Surg., 45, 510-515, 1987.

19) Temple, N.J. and Basu, T.K. Protective effect of beta-carotene against colon tumors in mice. J.N.C.I. 78 (6): 1211-1214, 1987.

20) Mathews-Roth, M.M., Lausen, N., Drouin, G., Richter, A., and Krinsky, N.I. Effects of carotenoid administration on bladder cancer prevention. Oncology, 48, 177-179, 1991.

21) Santamaria, L., Bianchi, L., Bianchi, A., Pizzala, R., Santagati, G., and Bermond, P. Photomutagenicity by 8Methoxypsoralen with and without singlet oxygen involvement and its prevention by beta-carotene. Relevance to the mechanism of 8-MOP photocarcinogenesis and to PUVA application. Med. Biol Environn., 12, (1), 541-549, 1984.

22) Santamaria, L., and Bianchi Santamaria, A. Cancer chemoprevention by supplemental carotenoids and synergism with retinol in mastodynia treatment. Med. Oncol. Tumor Pharmacother. 7 (3-3), 153-167, 1990.

23) Sporn, M.B., Dunlop, N.M., Newton, D.L. and Smith, J.M. Prevention of chemical carcinogenesis by vitamin A and its synthetic analogs (retinoids). Fed. Proc. 35: 1332-1338, 1976.

24) Santamaria, L., Benazzo, L., Benazzo, M., and Bianchi, A. First clinical case report (1980-88) of cancer chemoprevention with beta-carotene plus canthaxanthin supplemented to patients after radical treatment. Med. Biol. Environn., 16, 945-950, 1988.

25) Editorial. Vitamin A, retinol, carotene, and cancer prevention. Brit. Med. J. 281, 957-958, 1980.

26) Band P.R., Deschamps M., Falardeau M., Ladouceur J. and Cote J. Treatment of benign breast disease with vitamin A. Preventive Medicine, 13, 549-554, 1984.

27) Bianchi, L., Bianchi, A., Tateo, F., Pizzala, R., Stivala, L., and Santamaria, L. Reduction of chromosomal damage by bleomicyn in lymphocytes from subjects supplemented with carotenoids. Relevance in bleomicyn tumour chemotherapy. Preliminary results. Boll. Chim. Farmaceutico, 129 (12), 83s, 87s, 1990.

28) Bianchi, A., Roveta, G., Rizzi, R., Re, F., Pizzala, R.,et al. Increase in mouse liver mastocyte frequency induced by beta-carotene. Pharmacol. Res. 22s, 2, 1990.

29) Dell'Orti, M., Bianchi Santamaria, A. and Santamaria, L. Survival increase by beta-carotene supplementation in non-surgically treatable lung cancer. A preliminary study. In progress. 